NREL/TP.620.25939

LBNL-42286

February 1999

\title{
Green Power Marketing in Retail Competition: An Early Assessment
}

Ryan Wiser, Ernest Orlando Lawrence Berkeley National Laboratory Jeff Fang, Kevin Porter, and Ashley Houston, National Renewable Energy Laboratory

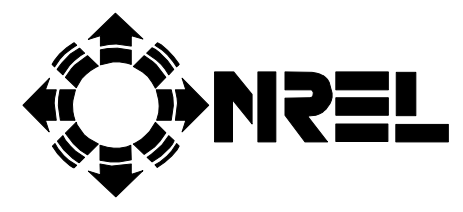

National Renewable Energy Laboratory

A national laboratory of the U.S. Department of Energy

The Topical Issues Brief series is sponsored by

DOE's Office of Energy Efficiency and Renewable Energy

Office of Power Technologies 
NREL/TP.620.25939

LBNL-42286

February 1999

\section{Green Power Marketing in Retail Competition: An Early Assessment}

Ryan Wiser, Ernest Orlando Lawrence Berkeley National Laboratory Jeff Fang, Kevin Porter, and Ashley Houston, National Renewable Energy Laboratory

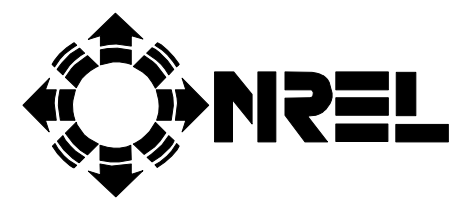

National Renewable Energy Laboratory

A national laboratory of the U.S. Department of Energy

The Topical Issues Brief series is sponsored by

DOE's Office of Energy Efficiency and Renewable Energy

Office of Power Technologies 


\section{NOTICE}

This report was prepared as an account of work sponsored by an agency of the United States government. Neither the United States government nor any agency thereof, nor any of their employees, makes any warranty, express or implied, or assumes any legal liability or responsibility for the accuracy, completeness, or usefulness of any information, apparatus, product, or process disclosed, or represents that its use would not infringe privately owned rights. Reference herein to any specific commercial product, process, or service by trade name, trademark, manufacturer, or otherwise does not necessarily constitute or imply its endorsement, recommendation, or favoring by the United States government or any agency thereof. The views and opinions of authors expressed herein do not necessarily state or reflect those of the United States government or any agency thereof.

Printed in the United States of America

Available to DOE and DOE contractors from:

Office of Scientific and Technical Information (OSTI)

P.O. Box 62

Oak Ridge, TN 37831

Prices available by calling 423-576-8401

Available to the public from:

National Technical Information Service (NTIS)

U.S. Department of Commerce

5285 Port Royal Road

Springfield, VA 22161

703-605-6000 or 800-553-6847

or

DOE Information Bridge

http://www.doe.gov/bridge/home.htm 


\section{Contents}

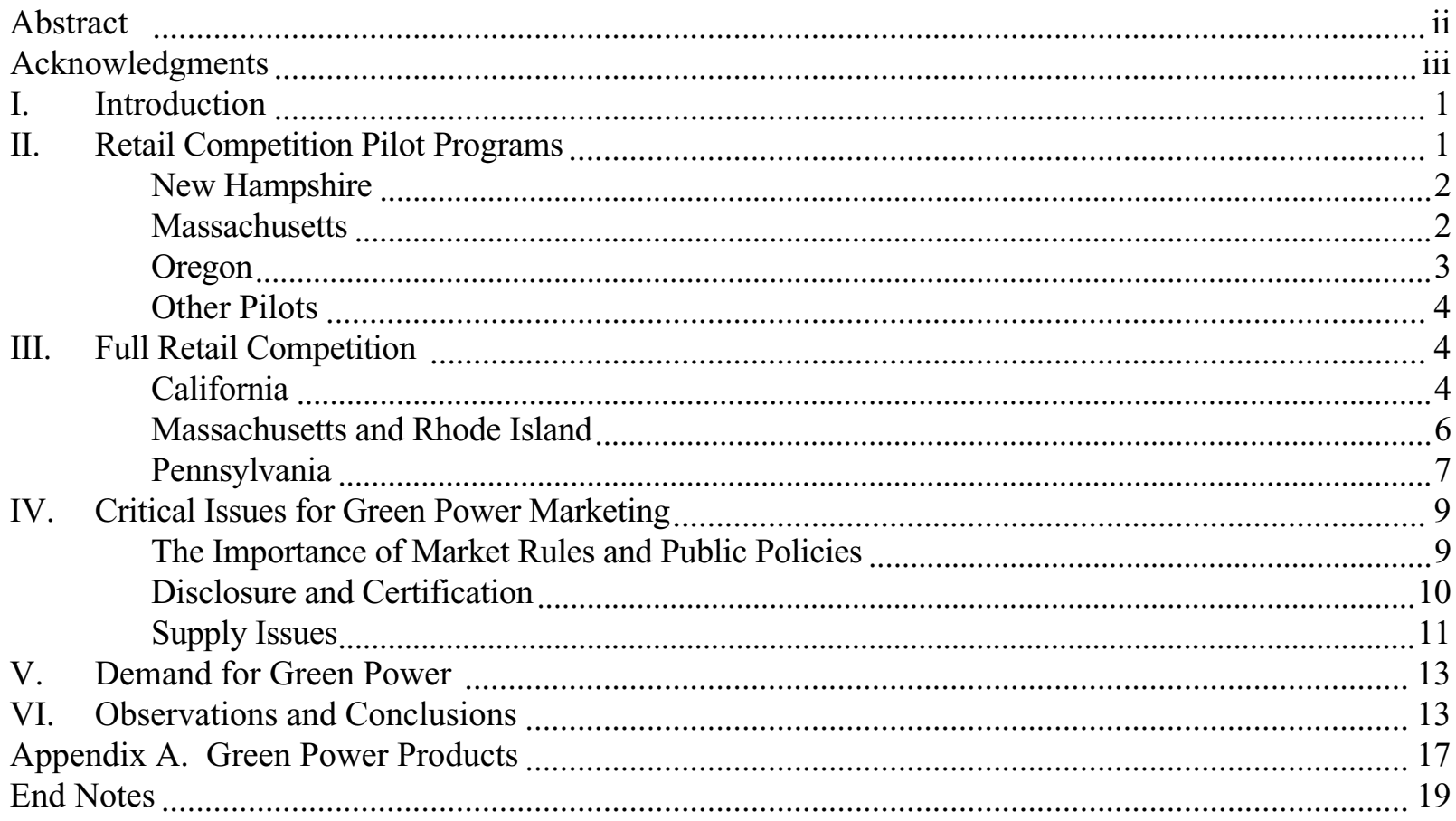

\section{Tables}

Table 1. Environmental Characteristics of Products Offered in Pilots and Full Competition ...............12

Table A-1. Green Power Products Offered Under Retail Competition to Residential Consumers ....... 16 


\section{Abstract}

Green power marketing - the business of selling electricity products or services based in part on their environmental values - is still in an early stage of development. This Topical Issues Brief presents a summary of early results with green power marketing under retail competition, covering both fully competitive markets and relevant direct access pilot programs. The brief provides an overview of green products that are or were offered, and discusses consumers' interest in these products. Critical issues that will impact the availability and success of green power products under retail competition are highlighted. Some of the key observations and conclusions of the work include:

- Experience from pilot programs in New Hampshire, Massachusetts, and Oregonwhile insightful in many respects—should not be broadly generalized. The direct access pilot programs in these three states all included green marketing. Yet only a fraction of the green products were differentiated based on their renewables content, and the environmental quality of many of the products has been questioned. Because of the nature of pilot programs, however, there are limits to what can be learned from these experiences.

- Green power markets have developed in all four states currently open to full competition. Experiences in the more fully competitive markets of California, Massachusetts, Rhode Island, and Pennsylvania provide a more realistic test of green marketing. These markets have only been open for a short time, and each differs substantially. Green power marketing is occurring in each market, however, and a total of 20 green power products have been launched. All of these products have been differentiated based on their renewables content, and $60 \%$ of the products include commitments to incorporate some new renewables over time. While concerns remain over the environmental and resource content of some products, overall product quality is superior to that seen in the pilot programs.

- The availability and success of green power products will hinge on several factors, including the regulatory rules and public policies established at the onset of restructuring. Differences among the markets discussed here can largely be traced to the design of specific market rules and public policies, particularly the default generation price offered by incumbent utilities. For the green market to succeed, regulators and policymakers will have to develop market structures, rules and policies in ways that are at least neutral to, and perhaps even support, this emerging new market. Surprisingly, market rules that promote vigorous price competition and overall customer switching appear especially important.

- Environmental disclosure requirements and certification programs may also play an important role in the success of green power markets. Given ongoing concerns about the credibility and environmental value of some of the green power products, customer information requirements and credibilityenhancing programs may be critical.

- Evidence to date shows that green products have had some success in markets newly opened to competition. Niche markets clearly exist for green power. Residential demand has been most prominent, though nonresidential demand has been more significant than many expected. Nonetheless, it will clearly take time for the green market to mature, and there remain legitimate concerns about the ability of customer-driven markets to support significant amounts of renewable energy. Unfortunately, there is currently insufficient data with which to predict the long-term prospects for green power sales with any accuracy. 


\section{Acknowledgments}

Green Power Marketing in Retail Competition: An Early Assessment was prepared by Ryan Wiser, Lawrence Berkeley National Laboratory (LBNL), and Jeffrey M. Fang, Kevin Porter, and Ashley Houston, National Renewable Energy Laboratory (NREL), for the Office of Power Technologies of the U.S. Department of Energy (DOE). The authors would like to acknowledge Joe Galdo, DOE, for the guidance and personal support he provided to this project. They also wish to thank the following reviewers for their comments and suggestions: Larry Goldstein (NREL), Joe Eto (LBNL), Blair Swezey (NREL), Liz Robinson (Energy Coordinating Agency of Philadelphia), Michael Tennis (AllEnergy), Alan Nogee (Union of Concerned Scientists), Kathy Phillips-Israel (Portland General Electric), Ed Holt (Ed Holt \& Associates), Bob Grace (consultant), Nils Bolgen (Massachusetts Division of Energy Resources), and Mary Kilmarx (Rhode Island Public Utilities Commission). 


\section{Green Power Marketing in Retail Competition: An Early Assessment}

\section{Introduction}

Under retail competition, electricity consumers can choose among multiple suppliers, service options, and products. Their purchase preferences and decisions can influence the types of service options offered and the resources from which electricity will be generated. Consumer demand for "environmentally preferable" sources of electricity may therefore increase the deployment of renewable energy in the marketplace, namely biomass, geothermal, solar, wind, and hydropower resources. In this respect, green power marketing the business of selling electricity products or services based on their environmental values - may play a role in renewable power development.

Some states and utilities have conducted pilot programs to gain experience with retail competition. Other states have proceeded directly to full retail competition. By early 1999, nearly 20 states had acted to restructure their electric industries and to develop retail competition over time. ${ }^{1}$ Though price-based competition is expected to be fierce, green power marketing has also emerged as one way of attracting customers in many of the states and pilot programs where retail competition has begun. Residential consumers have been the primary targets of these green suppliers, but larger customers have also expressed some interest in green purchases.

Whether or not green power marketing will provide significant support to renewable resources has been debated extensively ${ }^{2}$. The purpose of this Topical Issues Brief is to present an early assessment of green power marketing under retail competition. Section II covers retail competition pilot programs. Section III describes early experience in four competitive markets, including California, Massachusetts, Rhode Island, and Pennsylvania. Section IV discusses critical issues that have emerged from experiences to date and that will affect the success of green power marketing. Section $\mathrm{V}$ provides insight into consumer interest in and demand for green power products. The brief ends with conclusions and observations.

\section{Retail Competition Pilot Programs}

Either on their own initiative or by legislative or regulatory orders, utilities in 10 states have started retail competition pilot programs. ${ }^{3}$ Under these controlled tests, a selected number of customers are given the option to buy power from alternative suppliers. Pilot programs are often implemented with the objectives of gaining experience with retail competition, ironing-out operational, administrative and logistical issues, and exploring the impact of retail competition on product offers, electricity prices, and consumer purchasing decisions. ${ }^{4}$ Of the 10 pilot programs, significant green power marketing activity has occurred only in those located in New Hampshire, Massachusetts, and Oregon.

Before results from these three pilots are discussed, it should be emphasized that there are clearly limits to what can be learned from pilot programs. ${ }^{5}$ First, pilots are typically small, of limited duration, and are sometimes restricted to certain customer classes. Each of these factors have and will affect the green product offerings. Second, participation in pilot programs by green power marketers has often been driven by a desire to test different marketing concepts, not by short-term profit motives. After all, within the context of a pilot program, it can be extremely difficult and costly to target marketing messages to just those consumers eligible to participate. Under a more fully competitive market where profit motives are likely to be stronger, marketer participation, product design and pricing, and customer participation can all be expected to differ substantially. Third, many of the pilots have not been designed to mimic full retail competition, and therefore offer an artificial environment in which to test market response. For example, by disallowing electric utilities full stranded cost recovery for those customers who switched suppliers, many of the 
pilot programs guaranteed price savings to those customers. As a result of these three factors, the green marketing experience from the three pilots discussed below, while insightful in many respects, should probably not be broadly generalized.

\section{New Hampshire ${ }^{6}$}

The New Hampshire retail competition pilot program was the first in the nation to offer direct access to a limited number of customers in all customer classes. With ground rules established by the New Hampshire Public Utilities Commission (NHPUC), the 2-year, statewide pilot program began in May 1996. The pilot has since been continued indefinitely, though marketing to smaller consumers slowed considerably after the first several months. The pilot encompasses $3 \%$ of the state's electric load, prorated across customer classes, including 14,765 residential, 1,728 commercial, and 16 industrial customers.

More than 30 companies registered as electric suppliers in the pilot program, and a wide variety of marketing claims and value-added products and services have been offered. Of the dozen suppliers that marketed to residential consumers, at least six were engaged in some form of green marketing. Several of the "green" products offered by these companies were differentiated not by the source of their power supply, however, but by the environmental record of the company or by the non-energy products and services that were offered. Of the three products that were differentiated based in part on their power supply, to the extent there was a renewable energy component, it was derived primarily from existing hydroelectric facilities (see Appendix A). Neither non-hydro nor new renewables were included in the mix of these products to any large extent.

- Green Mountain Energy Partners offered a 97\% hydroelectric product from a partnership with Hydro-Quebec.

- Northfield Mountain Energy marketed pumpedhydro, neglecting to mention the sources of electricity required to pump the water uphill.

- Working Assets listed the resources it would not use: nuclear power, coal, and HydroQuebec.
Other suppliers, including Granite State Energy, Central Maine Power, and PSNH Energy used image advertising and/or offers of ancillary environmental goods and services to position their products as green. These included energy efficiency information, products and services, donations to environmental and community groups, and free bird feeders. Though these actions may help reduce pollution, improve energy-efficiency, and enhance environmental awareness, they do not support renewable energy.

The pilot was designed so that nearly all residential participants (even those purchasing from green providers) would save at least $10 \%$ on their electric bills when compared to existing utility rates. Of the non-utility electricity suppliers, however, the green suppliers did charge up to $1 \phi / \mathrm{kWh}$ more for their services than did their nongreen counterparts.

No public data are available on actual consumer responses to the product choices. However, a consumer survey conducted for the NHPUC provides some insight into what influenced participants' choices. In this survey, 20\% said that the environmental message strongly influenced their supplier and product choices $(17 \%$ indicated that the environmental message had a moderate influence). The appeal of renewable energy had a strong influence for $17 \%$ and a moderate influence for $13 \%$ of those surveyed. ${ }^{7}$ Despite these promising survey results, it is important to recognize that very few residents actually switched suppliers in the pilot program. In fact, even of those who elected to participate in the pilot, $40 \%$ ultimately decided not to switch suppliers at all, perhaps suggesting that these consumers were either unhappy with their product choices or unwilling to go through the hassle of sifting through the barrage of marketing material.

\section{Massachusetts $^{8}$}

In Massachusetts, the Massachusetts Electric Company (MECo) established a residential and small-business customer pilot program beginning on January 2, 1997. The pilot ran for a year until full retail competition became available. Whereas New Hampshire set few restrictions for supplier participation, the MECo pilot took a more 
controlled approach, selecting six companies to offer a number of different products in just four cities and preparing a booklet for customer participants describing their options. Approximately 4,750 residential and 550 business consumers subscribed to the pilot and switched suppliers.

Although the pilot's primary purpose was to test billing and metering logistics, MECo was also interested in ensuring participation in the pilot by offering both cost savings and other value-added services. For this reason, of the products selected by the program administrator to be offered to consumers, four were green power products marketed to residential consumers (see Appendix A) and three were green products offered to commercial accounts. ${ }^{9}$

Of the four green products offered to residential consumers, two were differentiated based on their power supply. The renewable energy component was again derived primarily from existing hydroelectric facilities. Other, non-hydro renewable resources were used sparingly.

- $\quad$ Northfield Mountain Energy marketed a 100\% hydro product.

- Working Assets again listed the resources it would not use: nuclear power, coal, and HydroQuebec.

Two additional green products, those offered by AllEnergy and Enova Energy, relied primarily on the provision of ancillary products and services to obtain a green position in the marketplace. For example, Enova provided a variety of environmental literature, a raffle for an electric vehicle, and matched donations to local environmental projects. AllEnergy offered the retirement of sulfur dioxide emission allowances and the construction of small photovoltaic (PV) facilities on community buildings.

As in New Hampshire, all products offered in the pilot provided cost savings to the average consumer when compared to existing MECo rates (to do this, MECo was required to forego full stranded cost recovery). Relative to other nonutility suppliers, however, some of the residential green power products were more expensive (by
$1.1 \phi / \mathrm{kWh}$ at most). Two of the green suppliers offered prices that were competitive with their nongreen counterparts.

Though the majority of consumers that switched providers opted for one of the lowerpriced products, $31 \%$ of the residential and $3 \%$ of the business accounts signed up with providers that offered green options. In a survey of participants, $16 \%$ of the residential participants cited environmental and social concerns as the primary reason for selecting their supplier, whereas $2 \%$ of commercial participants cited this reason. Interestingly, one of the most expensive residential green products, that offered by Working Assets, actually received the most market share among the green options.

These results should be viewed with caution, however, because only $3.5 \%$ of those residential customers that could have switched did so. The vast majority of residential customers elected to stay with their existing utility supplier, and the residential portion of the pilot was therefore not fully subscribed. As a result, consumers that did switch may have had a higher-than-average propensity to choose green power (i.e., a large number of "green" individuals may have opted to participate in the pilot because of the opportunity to pick green power). If a higher number of consumers had switched, the fraction of total consumers selecting a green option might decrease.

\section{Oregon ${ }^{10}$}

Portland General Electric (PGE) filed a plan for a direct-access pilot program in August 1997. The "Customer Choice Pilot Program" ran from December 1, 1997 through December 31, 1998, and allowed 50,000 retail consumers in four Oregon towns to choose their electric supplier. In addition, beginning in October 1997, all of PGE's large industrial accounts were eligible to participate.

Fourteen marketers were certified to provide electricity services under this program. Eight of these marketers were active in the pilot, but only Enron Energy Services (EES) and Electric Lite opted to serve residential households. These two companies offered a total of three products to 
residential consumers, including one green power option marketed by Electric Lite. The resource mix for this product consisted of $26 \%$ geothermal, $25 \%$ landfill gas, $25 \%$ hydro, and $24 \%$ natural gas, oil, coal, and nuclear resources. The cost premium for the product was $1 \phi / \mathrm{kWh}$ compared to Electric Lite's price-based offering, which was itself priced below the standard service offered by PGE. As of mid-1998, however, both EES and Electric Lite had ended their marketing efforts in Oregon.

By the end of the pilot in December 1998, $36 \%$ of residential consumers in the pilot area were aware that they were eligible to switch. Overall switching was rather high, with $14 \%$ of eligible residential consumers, $69 \%$ of eligible large industrial and commercial consumers, and $31 \%$ of eligible small to medium commercial customers switching providers (therefore, a relatively large fraction of "aware" customers actually switched).

Electric Lite garnered approximately 3,200 of the 6,400 residential consumers that switched providers, and 4,600 total customers. According to a PGE representative, however, just $1.7 \%$ of Electric Lite's residential customers and $0.4 \%$ of their commercial customers chose the green power option, with the majority selecting Electric Lite's low-cost product. ${ }^{11}$ In aggregate then, (including Enron's residential customers), only $0.85 \%$ of the residential consumers that switched providers in the pilot appear to have selected a green option. This is a much lower response to green power than that witnessed in the New Hampshire and Massachusetts pilots. One possible explanation is that Electric Lite began marketing its green option only after the pilot program had been operating for several months. It is quite possible that residential customers with a predilection to switch had already done so by the time the green product was available.

\section{Other Pilots}

Beyond these three programs, a number of additional pilots have been established throughout the country. In each of these, green marketing has played a minimal role at best. Some of the possible reasons for this lack of green marketing activity include:
- Participation Restrictions: Many pilots have restricted participation, explicitly or implicitly, to large customers, whereas green power is often best targeted to smaller residential and business customers.

- Competing Market Opportunities: Marketer participation in the New Hampshire, Massachusetts, and Oregon pilots was largely driven by a desire to test different marketing concepts, not by the prospect of garnering significant profit. Given the opportunity to now participate in larger markets, interest in pilot programs has diminished.

- Green Power Supply: In some pilots, green power supply may simply not be available.

\section{Full Retail Competition}

Given the unavoidably artificial environment of a pilot program, a more comprehensive assessment of the viability of green power marketing will come from those states that are more fully restructuring their electric industries. Here we highlight early results from California, Massachusetts, Rhode Island, and Pennsylvania. In this discussion, an "eligible renewable" resource is defined consistently with California law and the Green-e certification program, and includes biomass, solar, wind, geothermal, and small hydro less than or equal to 30 megawatts. For a tabular comparison of the green products offered in these markets, see Appendix A.

\section{California $^{12}$}

California's \$20 billion power market opened on March 31, 1998, and all consumers located within the service territories of the three large, investor-owned utilities were given the opportunity to select a new electric provider (representing $75 \%$ of all load). California's market has attracted more interest by competitive suppliers than Rhode Island and Massachusetts (discussed later). Yet these suppliers have been particularly interested in the largest electricity customers. According to the California Public Utilities Commission (CPUC), nearly 30 marketers are registered to offer products to residential households, but only eight companies currently have products on the market for these customers. 
Because of the way the market is structured in California, it is virtually impossible to earn a profit by offering smaller consumers price savings. The resultant lack of price competition is typically attributed to two primary factors. First, due to high customer acquisition costs, signing up an average residential consumer in the early years of restructuring may cost well over $\$ 100$ (Enron reportedly spent $\$ 10$ million to attract 30,000 customers, a $\$ 300$ per customer cost). With razorthin profit margins, such acquisition costs can easily swamp any savings that might be available on the commodity cost of power. Second, the default generation price offered by incumbent utilities to consumers that choose not to switch suppliers is low. If a residential consumer switches suppliers, only the commodity power-exchange clearing price is subtracted from their overall utility rate. Because the power exchange is a large, wholesale exchange without a retail markup, competitive suppliers are therefore forced to compete, at retail, with a low default price, leaving little or no margin for entry.

One result of this market structure, and the consequent lack of price competition, is that one of the only avenues into California's residential market is to offer premium-priced, value-added products and services, the most prominent of which are turning out to be green power products. As a result, six of the eight marketers currently selling to residents offer green power products, and the larger, well-capitalized companies targeting households are avoiding the price-based market altogether and are focusing their efforts exclusively on green power alternatives.

Incentives provided by the California Energy Commission (CEC) to renewable generators and green power retailers have also helped stimulate the market for green power sales. In fact, in January 1999, the only major supplier offering price discounts to residential customers (Commonwealth Energy) switched all of their residential and small commercial customers to a $100 \%$ renewable energy product. Concomitantly, the company began offering the same product to new customers at a small discount off of utility tariffs. Commonwealth was able to offer this service because of the $1.5 \phi / \mathrm{kWh}$ subsidy provided by the CEC to marketers for renewable energy sales. Though temporary - the incentive level will decline as overall renewables demand increasesthe incentive currently makes it cheaper to supply residential customers with renewable energy than with any other energy source.

As shown in Appendix A, the six green power retailers currently offer 13 green power products to residential consumers across the state. These retailers include Edison Source, Green Mountain Energy Resources (GMER), PG\&E Energy Services, Commonwealth Energy Corporation, cleen ' $n$ green, and Keystone Energy Services. The green product offered by Enron Energy Services before they withdrew from the residential market is also included because the company continues to serve those customers that signed up before May 1998.

After an initial influx of marketing in early 1998, some of these companies have scaled back their advertising efforts. At the same time, new companies continue to enter the green power market, and some of these newer players are beginning to use less traditional marketing approaches like agent-based, network, and affinity marketing. PowerSource, PowerCom Energy, Communications Access, and others, for example, are poised to enter the green power fray. Additional companies are positioning themselves to provide residential, grid-connected PV products (including GMER). The Sacramento Municipal Utility District also offers a number of green power products, but only to consumers within their service territory. A final group of suppliers in California's competitive marketplace have focused on wholesale green power transactions and/or the large-customer market, including the Automated Power Exchange, Foresight Energy, PacifiCorp, the Bonneville Power Administration, the Environmental Resources Trust, Enron, New West Energy, and Dynegy.

The various residential green products offered by retailers differ in many ways, including resource content, pricing, term of agreement, billing method, and the provision of various sign-up bonuses. Including Enron's product, 13 of the 14 products include substantial quantities of "eligible" renewable energy (defined to include wind, solar, geothermal, biomass, and small hydropower). These include one $20 \%$ renewables product, four 
$50 \%$ products, two $75 \%$ products, and six $100 \%$ products. The one remaining product contains $100 \%$ hydropower. Most of the supply for these 14 products comes from existing resources, but an additional attribute of some of the products is the inclusion of "new" renewables (i.e., newly constructed renewable facilities). In fact, eight of the 14 products include commitments to supply some new renewables $(5 \%-25 \%)$ over time. The prices for the green products range from an $0.1 \notin / \mathrm{kWh}$ discount to a $3.5 \phi / \mathrm{kWh}$ premium relative to utility service for the average residential consumer.

The market in California has only been open a short time, and consumer response to the product offerings should therefore be considered preliminary. Data provided to the CPUC indicate that 78,800 residential consumers $(0.9 \%$ of those eligible), 23,600 small commercial consumers (2.4\% of those eligible), 9,300 large commercial consumers ( $4.7 \%$ of those eligible), and 880 industrial consumers ( $18.1 \%$ of those eligible) had switched suppliers by the end of December 1998. These switchers accounted for $11.6 \%$ of all load eligible to switch, but $97 \%$ of this was comprised of the larger consumers. Residential switching has been relatively low. Yet, while residential switching has not taken off as rapidly as some marketers had hoped, the level of actual switching is not terribly surprising given the new and emerging market and the lack of price savings available to smaller consumers.

Given the dearth of other product offers, industry experts and green power marketers estimate that approximately $40 \%-50 \%$, or 30,000 40,000 , of the residential switchers have selected a green power product. Based on the level of their marketing effort, GMER has likely received a good share of this market. Yet, because of the incentives offered by the CEC to marketers for renewable energy sales, individuals that signed up for pricebased products with Commonwealth and Enron have been "upgraded" to renewable products at no additional cost. As a result, virtually every residential customer that has switched providers in California is being served by a renewable energy product, making Commonwealth and Enron major suppliers of renewable energy to residential customers in the state.
Though residential consumers are the primary market for green power in California, they are clearly not the only targets of retail marketers. Indeed, in part because of the slow switching rate among residents, marketers are increasingly recognizing the importance of nonresidential demand for green power. Larger consumers that have announced green power purchases or commitments include Toyota Motor Sales USA, Patagonia, the City of Santa Monica and Chula Vista, the University Students' Cooperative Association at UC Berkeley, and several Episcopal churches. Based on discussions with marketers and other industry observers, it is apparent that these nonresidential consumers could easily be contributing $25 \%$ or more of total green power demand.

Using the information on residential and nonresidential demand highlighted above, it can be estimated that about $4 \%-5 \%$ of the total load that has switched providers in California is being served by a green power product. Because some of Commonwealth and Enron's customers did not actively switch to a green offering, however, approximately $2 \%-3 \%$ of the total load that has switched is actually paying more for a green product.

\section{Massachusetts and Rhode Island}

Full competition in Massachusetts began on March 1 and in Rhode Island on January 1, 1998. Because the two markets are similar in many respects, they are discussed jointly here. Unlike California and Pennsylvania, very little marketing activity has occurred in either Massachusetts or Rhode Island. As of February 1999, 17 suppliers and nine brokers were licensed to do business in Massachusetts and 35 suppliers were registered in Rhode Island. Yet only one of these suppliers, AllEnergy Marketing Company, has launched a product in these states for residential consumers and actively advertised its services (another supplier, Sunshine Energy, has a limited marketing effort in Rhode Island). Even for the largest consumers, there has only been modest interest by suppliers.

According to marketers, the market rules established in both of these states make them 
unattractive prospects in the short term. Most importantly, to ensure a near-term rate reduction for consumers in Massachusetts, the incumbent utilities initially offered generation service at

$2.8 \notin / \mathrm{kWh}$-consumers must also pay for the cost of other necessary services, including transmission, distribution, stranded costs, and other regulated charges. Because the cost of electricity in Massachusetts' wholesale market runs from 3.5$4 \phi / \mathrm{kWh}$, it has been practically impossible for a competitive supplier to undercut the utility price. Residential consumers would likely have to pay a $1 \notin / \mathrm{kWh}$ premium just to have the privilege of choosing a competitive supplier. Rhode Island has created a similar market structure, with market rates for electricity generation initially exceeding the utility price by over $0.5 \mathrm{k} / \mathrm{kWh}$. Though these default utility generation prices (often called the "standard offer") have and will continue to rise in future years, they are stifling competition for the time being. Other, secondary issues, including initially uncertain market rules and environmental disclosure regulations in Massachusetts, incomplete unbundling of billing services, and a ballot referendum to repeal the Massachusetts restructuring legislation (which has since failed), have also dampened market activity.

To overcome the low cost of default utility service, AllEnergy created an innovative, green power offering called ReGen. This green power product is sold separately from electric supply, allowing consumers to remain with their low-cost utility service while still supporting renewable energy. AllEnergy bills separately for its product, and then supplies the appropriate quantity of renewables into the New England grid. Because the product is not linked with a consumer's actual electricity supply, it can be offered in states not yet open for retail competition. The product is therefore offered throughout New England, though AllEnergy has focused its marketing in Massachusetts and Rhode Island. The product can be purchased in $2,000 \mathrm{kWh} /$ year blocks at $\$ 8 /$ month for the first and $\$ 6 /$ month for subsequent blocks, where each block includes 100\% new renewable energy. During the first year, sources for the product are expected to be $99.5 \%$ new landfill gas and $0.5 \%$ new photovoltaics. In the future, AllEnergy expects to increase PV and add wind to the product content. AllEnergy's green power demand has already resulted in the installation of some PV and the company is currently in the development phase for a 7.5 MW wind facility in Massachusetts.

In addition to the AllEnergy product, there has also been some interest in the rooftop PV market. Specifically, Solar Works has received some public funding in Rhode Island to market PV systems, and Sun Power Electric is building rooftop PVs and selling that power both to PV site hosts as well as to green power marketers and other consumers. A growing cooperative movement in the region may provide a low-cost mechanism for marketers to access large numbers of potential green power customers. The Boston Oil Consumers Alliance, for example, is already aggregating their customers to buy green power from AllEnergy.

No data are available on how many customers have switched suppliers in either Massachusetts or Rhode Island, and AllEnergy has not reported consumer demand results for their green power product. Nonetheless, given the lack of interest on behalf of suppliers, it is doubtful that many consumers have taken the opportunity to switch from their utility service. On the day of its launch, the Union of Concerned Scientists announced the purchase of 30 blocks of AllEnergy's green power product. AllEnergy has since begun marketing their services, but has reported that attracting customers is a difficult, complicated, and time-consuming process. ${ }^{13}$

\section{Pennsylvania}

The Electricity Generation Customer Choice and Competition Act, enacted in December 1996, provided many of the basic ground rules for establishing retail competition in Pennsylvania. Subsequently, the PUC negotiated detailed restructuring settlements with each utility. As a result, beginning in January 1999, customers representing two-thirds of industrial, commercial, and residential load were eligible to select a new power provider, with the remaining customers eligible in January 2000 (some utilities offered choice to all customers beginning January 1999).

Though the market only opened in January 1999, consumer choice in Pennsylvania is already 
shaping up to be far different from that witnessed in California, Rhode Island, or Massachusetts. Specifically, in Pennsylvania, several (though not all) of the utilities offer default generation service at a price that exceeds that available on the open market. Consequently, consumers that switch suppliers are given a realistic opportunity for significant cost savings - up to $15 \%$ - and green power can be offered at a lower overall cost relative to utility rates. The Pennsylvania PUC is also actively promoting choice and encouraging consumers to choose a new provider. Therefore, despite a dearth of renewable power supply, limited disclosure requirements, concerns over the availability and pricing of "capacity," a phase-in of full, direct access, and market rules that differ by utility service territory, a number of marketers are active in the Pennsylvania market. Some of these marketers are offering green power products.

In PECO's service territory, where the bulk of the marketing is focused, 48 suppliers are registered to offer services to commercial and/or industrial clients and 18 suppliers are registered to offer services to residential households. Eleven of these residential suppliers have announced prices and are already active. Three of these have begun to sell green power products: Conectiv, GMER, and the Energy Cooperative Association of Pennsylvania. GMER is offering three green products statewide:

- Eco Smart, consisting of $99 \%$ natural gas and/or large hydro and 1\% new landfill gas

- Enviro Blend, containing 47\% existing small hydro and landfill gas, 3\% new landfill gas, and $50 \%$ natural gas and/or large hydro

- Nature's Choice, including 95\% existing small hydro and landfill gas and 5\% new landfill gas.

GMER has also announced its intention to construct multiple PV facilities throughout the state, beginning with a 50-kilowatt plant. The price of GMER's three products varies greatly by utility service territory, and the Eco Smart product is sold at a discount from 1999 utility rates in some areas. On average, green power price premiums are lower than those seen in California.
Conectiv offers both price-based products and two green power products in PECO's service territory:

- Nature's Power 100, containing $100 \%$ renewable energy ( $50 \%$ biomass, $50 \%$ small hydro)

- Nature's Power 50, containing 50\% renewable energy ( $25 \%$ biomass, $25 \%$ small hydro) and $50 \%$ nonrenewable resources.

The prices for these two products are also lower than those witnessed in California, Massachusetts, and Rhode Island. Finally, the Energy Cooperative Association of Pennsylvania, a member-based cooperative, sells Conectiv's two products to its members at a discount.

Because of the way the market was structured - especially the ability for alternative suppliers to offer price savings - many industry observers expected a significant amount of nearterm customer switching in Pennsylvania. While the market has only recently opened, available switching data support this expectation and show that the Pennsylvania market is already far more vibrant than those in the other states reviewed here. Most importantly, a recent statewide poll undertaken by the PUC suggests that 425,000 residential consumers, or almost $10 \%$ of the residents in the state, had already switched providers as of January 1, 1999. Considering the $0.9 \%$ response rate in California after 9 months, this is an astounding response. Moreover, green power sales appear to be brisk in the Pennsylvania market. GMER has reported being the number one or number two residential supplier in each utility service territory, though GMER's lowest-priced green product has received the most interest by customers. In addition, industry sources estimate that approximately 100,000 of the 450,000 residential switchers have selected one of the "green" power products listed earlier. This represents over $20 \%$ of the residential switchers and about $2 \%$ of all residential customers in the state. On this basis alone, it is evident that Pennsylvania has proven to be a more successful market for green power sales than California, Massachusetts, or Rhode Island. 


\section{Critical Issues for Green Power Marketing}

What are the factors that encourage or dissuade green power suppliers to participate in specific markets? What variables affect both the success of green power products and the type of products that are offered? This section discusses the importance of market rules and public policies, the possible need for disclosure and certification, and a variety of supply-related issues. Each of these factors influence whether and what type of green products are made available to consumers and whether these products will be successful.

\section{The Importance of Market Rules and Public Policies $^{14}$}

The success of retail markets for green electricity, however measured, will depend not only on the actions of private market actors but also on the detailed "market rules" established by regulators and legislators at the onset of restructuring and on a variety of policies and programs intended to support the market. In fact, one need not look farther than the four competitive markets discussed earlier to show that the "rules of the game," especially the default generation price, will dictate the pace, success, and credibility of green power marketing.

In California, where many of the market rules and policies are relatively conducive to green power marketing, but the default generation price is set at the wholesale cost of generation, green power products are just about the only game in town for marketers interested in targeting residential consumers. Yet the low default price is discouraging the development of robust, pricebased competition (at least for smaller consumers) and has therefore inhibited customer switching. Thus, while value-added products and green power sales are playing a prominent role in the residential market, the overall size of that market has been rather limited.

In Massachusetts and Rhode Island, market rules were initially somewhat uncertain, some rules that are in place are not particularly favorable to green marketers, and the default generation price was set at a level below the cost of wholesale generation. As a result, very little competition of any form is occurring in those two markets, customer switching is negligible, and the green power market is basically stagnant.

Finally, there is Pennsylvania, where many of the basic rules are also unfavorable to marketers. For example, there are no fuel-source disclosure requirements, the rules differ by utility service territory, few efforts have been made to ameliorate concerns over market power, several utilities encourage customers not to switch, and subsidies are not widely available for renewable generators and green power marketers. Yet, the default generation price was set at a high level in several utility service territories in Pennsylvania, and consumer choice is being actively promoted by the state PUC. Consequently, even with a number of unfavorable market rules, there is active price competition and some momentum on the part of consumers to switch providers. Moreover, within this market structure, green power providers appear to be having far more success than in markets where price competition and switching are more limited.

Regulatory and public policy considerations clearly influence both the willingness of green power suppliers to enter competitive markets and the environmental credibility of the products and marketing claims of those suppliers. Somewhat surprisingly, the experience described in this paper shows that market rules that promote vigorous price competition and overall customer switching are especially important, even for the green power market. But beyond a high default generation price and those rules discussed above, what types of market rules and public policies are conducive to green power marketing?

In general, marketers believe that the first priority should be to design the basic market rules in ways that allow overall competition to emerge and that minimize barriers to entry. As a result, in a survey of United States green power marketers, the following market rules were viewed by most as particularly important: ${ }^{15}$ 
- A default generation price that is high enough to encourage entry by competitive suppliers (this was the single most important market rule identified by marketers).

- Direct access processing and service that is rapid, uniform, and consistent across utility service territories, and low customer-switching costs.

- A transition to a competitive market that is rapid, without pilots or phase-ins.

- Billing and metering services and costs that are fully unbundled.

- Stranded costs that are recovered quickly via a fixed $\phi / \mathrm{kWh}$ charge and rules that give utilities an incentive to mitigate the level of stranded costs.

- Meaningful protections against the abuse of market power.

- A careful balance between augmented consumer protection regulations and the added costs and burdens imposed on energy service providers.

- Publicly-funded consumer education on retail choice to offset consumer inertia and confusion.

Once this basic foundation for competition is established, marketers generally believe that a number of policies and programs specifically intended to encourage the green power market should be considered:

- Mandate fuel source and emissions disclosure, but only if simple and standardized.

- Avoid strict, non-uniform, governmental definitions of green power. Allow voluntary certification programs and environmental endorsements to help define the meaning of green power.

- Ensure that transmission-pricing rules do not disadvantage intermittent, low-capacity factor generators.

- Provide monetary incentives to green power marketers, consumers, and/or renewable generators.

- Fund consumer education campaigns on renewable energy.

It remains uncertain whether green power marketing will add substantially to existing renewables capacity levels-or even stem the possible decline in existing renewables generation-in the absence of more overt types of renewables policy. Traditional economic theory suggests that, in the case of green power, individual consumer demand will be unable to fully replace collective public policy measures. Therefore, in addition to those market rules and policies described above, policymakers have also considered broader public policies to support renewable energy, including distribution surchargefunded programs (often called a system-benefits charge) and renewables portfolio standards. Though the level of support differs dramatically, in each of the markets discussed earlier, namely California, Massachusetts, Rhode Island, and Pennsylvania, legislators and regulators have enacted one or both of these two policy approaches.

\section{Disclosure and Certification}

Research shows that consumers often do not link their electricity use with environmental harm, generally have inaccurate ideas about the resources used to generate their electricity, and wonder if they will get what they pay for if they buy green power. Consumers also have difficulty evaluating the barrage of advertising and marketing material associated with customer choice, are concerned about the reliability of their new provider, and expect exaggerated or misleading advertising claims by green power marketers. Not surprisingly, many consumers exposed to competitive electricity markets simply find choice overwhelming and, as a result, find it easier to do nothing. ${ }^{16}$

Early competitive markets are therefore very likely to be marked by consumer confusion, skepticism, and inertia. In fact, experience in the New Hampshire and Massachusetts retail competition pilot programs confirms these fears and demonstrates that some suppliers have an incentive to use misleading environmental claims and inferior green products to attract customers (lesser, but still serious, concerns have also been raised in California). These concerns and experiences suggest that, of the market rules and policies discussed earlier, both well-designed environmental disclosure regulations and green power certification efforts may play an especially important role. 
Mandatory disclosure of product information such as prices, resource mix, and environmental impacts is intended to facilitate the comparison of different electricity products and green claims. Disclosure may also provide the ancillary benefits of raising consumer awareness of non-price attributes to consider in purchase decisions and enhancing consumer protection by limiting false and/or misleading claims. On this premise, 11 states have either adopted legislation or are writing rules to require disclosure, and an additional 16 states are in various stages of consideration. ${ }^{17}$ In California, for example, the legislature requires retail suppliers to disclose the fuel mix of their products to customers. In Massachusetts, both fuel mix and pollutant emissions must be disclosed.

Unlike mandatory disclosure regulations, green power certification is a generally a voluntary, product-approval program based on standards set by the certifying organization. The effectiveness of various forms of product labeling has been debated; certification is not universally hailed. ${ }^{18}$

Nonetheless, the function of product certification is to provide an impartial, third-party endorsement to aid buyers in overcoming some of the problems of product selection, to prevent false and misleading advertising, and to spur suppliers to compete in offering environmentally preferable products. ${ }^{19}$

Administered by the Center for Resource Solutions, the Green-e Renewable Electricity Branding Project is the first program in the United States to certify green power products. The program is operating in California and Pennsylvania, and hopes to expand to New England shortly. To use the Green-e logo, product offerings must meet or exceed standards for renewable energy content and total air emissions, and must not include differentiated nuclear energy. Since the Green-e program is still young, its effect on building consumer confidence in green product offerings is difficult to gauge. Nonetheless, anecdotal evidence and a survey of marketers suggest that the program is already having a positive impact on the environmental attributes of the green products offered in California, that consumers are becoming increasingly aware of the brand, and that the brand is enhancing the stability of the green power marketplace by creating some confidence within the environmental community about the green product offerings. ${ }^{20}$

\section{Supply Issues}

Product content and resource supply issues are strongly related to green power market credibility. Table 1 provides summary statistics of key product content differences between those products offered under the pilots and those sold under full competition (ignoring renewables systems placed and used on site by customers). Marketers continue to experiment with new product designs and, as discussed below, improvements in the general environmental quality of the products would still be desirable. Comparatively speaking, however, Table 1 demonstrates that the environmental and resource characteristics of green products sold under full competition are superior to those supplied in the pilots.

In the New Hampshire and Massachusetts pilots in particular, a number of suppliers used image advertising and/or offers of ancillary environmental goods and services to position their products as green. Few products included substantial quantities of non-hydro renewable resources, and nearly all of the products repackaged existing resources rather than include new renewables supply. Under full competition, on the other hand, all of the green products are currently being differentiated based on their resource content and most incorporate a far higher percentage of renewable resources. Moreover, $60 \%$ of the products include a commitment to supplying some new renewables over time.

A number of factors are likely the cause of the divergence in product content between the pilot programs and those states more fully open to retail competition. First, the short duration and limited size of most pilot programs discourages suppliers from constructing new renewable plants. Recovery of investments in new facilities is uncertain in these instances, and there is generally insufficient lead-time to warrant developing new plants. Suppliers therefore rely on available existing resources, on image advertising, and on the provision of ancillary environmental goods. Under full retail competition, a greater opportunity exists to build new facilities. Second, marketers are 
Table 1. Environmental Characteristics of Products Offered in Pilots and Full Competition

\begin{tabular}{|l|l|l|}
\hline Product Content & $\begin{array}{l}\text { Retail Pilot Programs } \\
\text { (NH, MA, OR) }\end{array}$ & $\begin{array}{l}\text { Full Retail Competition } \\
\text { (CA, MA, RI, PA) }\end{array}$ \\
\hline Total number of green products offered to residential consumers & 11 & 20 \\
\hline Percent of green products differentiated based on resource content & $55 \%$ & $100 \%$ \\
\hline $\begin{array}{l}\text { Percent of green products with 50\% or more renewables content } \\
\text { (including large hydro) }\end{array}$ & $36 \%$ & $95 \%$ \\
\hline $\begin{array}{l}\text { Percent of green products with 50\% or more "eligible renewables" } \\
\text { content (biomass, wind, small hydro, geothermal, solar)* }\end{array}$ & $9 \%$ & $85 \%$ \\
\hline $\begin{array}{l}\text { Percent of green products that include a commitment to supply } \\
\text { some new renewables }\end{array}$ & $9 \%$ & $60 \%$ \\
\hline
\end{tabular}

*It is assumed that the hydro-based products in the New Hampshire and Massachusetts pilots consist primarily of large hydro resources.

becoming increasingly aware of the importance of renewables supply generally and new supply specifically. Especially in the New Hampshire and Massachusetts pilots, suppliers were experimenting with a variety of product concepts and marketing appeals. Now that marketers have some experience with direct access, including a recognition of the environmental backlash that resulted from the two pilots, they are more aware of product design challenges and the meaning of "green power" to environmental stakeholders. Finally, consumer protection regulations, disclosure and certification requirements, environmental endorsements, public information campaigns, and mandatory green power definitions are also pushing marketers to improve the environmental and resource characteristics of their products.

Despite improvements in product quality, however, some concerns remain with the characteristics of those products offered under full retail competition. Perhaps most importantly, despite the inclusion of some new renewables in the product content, the majority of products still largely rely on existing resources, many of which are utility owned. Of the 12 products that do incorporate some new renewable energy, the new content is typically relatively small-seven of the products include less than $15 \%$ - and the specific commitment to new resources is often somewhat vague. This has led to concerns that green power marketing is largely repackaging an existing mix of renewables that would have generated power absent consumer payments, yielding little immediate environmental improvement or incremental renewables supply. ${ }^{21}$

Though many of these are legitimate concerns, especially in the early years of green power market development there are several reasons why marketers are relying heavily on existing resources. First, given the high costs of attracting and acquiring customers in a deregulated environment, green suppliers are wary of charging too much for their services. Existing resources that have already recovered their capital costs are often much less costly than new projects that must recover both capital and operating costs. Second, and perhaps more importantly, it takes time and a serious, long-term commitment to develop new resources, and consumer demand for green power is still highly uncertain. Smaller companies in particular, faced with uncertain green power demand, simply do not possess the resources and credit to support significant quantities of new generation.

Until a positive record of consumer demand is established and green power marketers are on firmer ground, it will be difficult for most marketers and generators to finance new renewable facilities. As an interim measure, many marketers will therefore rely on lower-risk, existing resources whose output can be purchased now via short-term, flexible contracts. New mechanisms for risk allocation, risk management, and financing will be 
needed before substantial amounts of new renewables can be developed. If these mechanisms are worked out, and if demand solidifies and marketers obtain a stronger foothold in the market, green products can be expected to include greater quantities of new renewables in the future. ${ }^{22}$ It is apparent that many industry observers will rate the overall success of the green market based on its ability to deliver this new renewable energy supply.

\section{Demand for Green Power}

Residential consumers are widely regarded as offering the largest potential market for green power. In surveys, $40 \%-80 \%$ of these consumers state that they are willing to pay a small premium for renewable energy. ${ }^{23}$ Though the results of market research of this type should not be interpreted as an actual indicator of consumer demand, it does reveal broad interest in renewable resource purchases. But with retail competition, will consumers really demand green power and be willing to pay a premium for a product that provides environmental benefits to all?

Unfortunately, given the emerging nature of the green power market, it is not yet possible to draw strong conclusions regarding its ultimate size or its potential to create new markets for renewable energy. Further, the evidence presented in this paper offers a mixed review of green power marketing results to date.

In the Massachusetts and New Hampshire pilots, perhaps $20 \%-30 \%$ of residential consumers that switched providers selected a "green" product, suggesting a large role for green marketing. Moreover, in the more fully competitive markets of California, Massachusetts, Rhode Island, and Pennsylvania, large proportions of households that switch are selecting green power options. For example, virtually every residential switcher in California is being served by a green product, and approximately $40 \%-50 \%$ have opted to pay more specifically for a green power offering. And in Pennsylvania, where robust price competition exists, approximately $20 \%$ of residential switchers are selecting green options. It is difficult to extract robust conclusions from this data, however, or to extrapolate future green power demand from these early results:
- First, because of the way the pilots were designed, participants in New Hampshire and Massachusetts saved money regardless of which provider they chose (participants did, however, often pay more for the green options than for the cheapest alternatives). Green products may look more attractive in this environment than in one where significant premiums are required. Results in Pennsylvania, where premiums are generally low and green power demand is high, support this argument.

- Second, the green options offered in Massachusetts and New Hampshire, in particular, have been criticized for not being very "green." This helped hold down the green power price premiums and may have therefore attracted additional green demand. Yet, it is also possible that the poor quality of products limited interest among committed and knowledgeable environmentalists in "going green.”

- Third, in all cases, those who have or are switching providers may have a higher than average propensity to choose green. That is, some consumers may have participated in the pilots because they wanted the opportunity to buy green power. Likewise, given the way the market has been structured in California, Massachusetts, and Rhode Island, nearly all of the residential products are green offerings. As the markets more fully open and as more products become available, the percentage of switchers that pick a green option may well decline.

Finally, and most importantly, these results must be viewed in the context of the vast majority of consumers that have chosen not to switch providers. In Massachusetts and Rhode Island, precious few options are available to smaller consumers, and in California only $0.9 \%$ of the residential consumers had opted to switch providers by the end of December 1998. Even in the pilot programs, where consumer price reductions were assured, a large majority of consumers chose not to switch. Though the Pennsylvania market is shaping up as one where customer switching is much higher, in general newly restructured markets are 
expected to open rather slowly. After all, even if new competitors can offer significant savings and other benefits, the switching process itself entails large transaction costs for smaller consumers, especially in the time and effort required to gather information and evaluate offers. As a result, in the early years at least, the most important barrier to green power may well be an overall lack of switching activity.

Despite these caveats, early experience with retail competition does suggest that green power products will have some success in penetrating newly-opened electricity markets. First, environmental claims and the supply of renewable energy can clearly be used to capture at least a niche segment of residential consumers. Second, given the high proportion of residential switchers that are selecting green power products, there is at least the potential for a significant level of demand for green power as markets open and more consumers switch providers. Early experience in Pennsylvania is promising, with approximately $20 \%$ of the residential switchers selecting a green option even with substantial levels of overall switching and the availability of price-based options. Third, experience so far indicates that nonresidential consumers may prove to be an especially important target during the early years, as these electricity users have initially shown more interest in participating in retail competition and the per-kWh customer acquisition costs are lower than in the residential market. Based on a survey of green power marketers as well as evidence in California and certain utility programs, it looks as if these larger consumers could constitute $25 \%$ of total green demand. ${ }^{24}$

It will, however, clearly take some time for the market to develop. Moreover, legitimate concerns remain about the ability of consumer markets to support significant amounts of renewable energy and achieve environmental objectives. The long-term prospects for green power therefore remain uncertain, and marketers, policymakers, and advocates should not expect immediate results. Demand for new products often follows an "S" curve, starting slowly before proceeding through rapid growth. ${ }^{25}$ Experience in other markets suggests that it may take 10 years or more for green power to make significant inroads into the market, if ever. ${ }^{26}$ In fact, even the green marketers do not anticipate immediate results, but rather expect to garner $0.5 \%-2 \%$ of the residential market within 1 year after retail competition is allowed, and $4 \%-10 \%$ after 5 years. ${ }^{27}$

In the near term, then, niche markets for green power clearly exist and have the potential, if designed well, to provide a modest yet meaningful level of support to the renewables industries. Over the long-term, continued work by all parties will be required to lay the groundwork for a durable, sizable, and credible green power market.

\section{Observations and Conclusions}

Based on the results presented in this paper, we offer the following observations and conclusions:

First, the results of the pilot programs in New Hampshire, Massachusetts, and Oregon confirm that power marketers will offer green power products in a competitive context. All three pilots involved green power marketing and 11 separate green products were offered. Only a fraction of these products were differentiated based on their renewable energy content, however, with several suppliers relying on image advertising and ancillary environmental goods to "green" their product offers. In large part because of the short duration and small number of customers eligible to switch providers in these pilot programs, only one product included a commitment to supply new renewables. Given the nature of pilot programs in general, however, these results should not be used heavily in assessing the prospects for green power marketing under full retail competition.

Second, though the markets are still very young, experience in those states more fully open to retail competition (California, Massachusetts, Rhode Island, Pennsylvania) is more likely than the pilots to provide a realistic indication of the opportunities and pitfalls of green power marketing. Each of these markets differ substantially, but all include green power marketing activity. A total of 20 products are offered by nine retail marketers in these states, and additional suppliers continue to enter the markets. Though concerns about the 
quality of the "green" products remain, the environmental and resource characteristics of the products sold under full competition appear superior to those supplied in the pilot programs. All 20 of the green products are differentiated based on their renewable energy content, and $60 \%$ commit to adding some new renewables to their portfolios over time. There are a number of barriers to including new renewables, however, and most of the products rely heavily on existing resources. Greater commitments to incremental sources are expected to be made as the market matures, and many industry observers will rate the long-term success of the market on its ability to deliver this new renewables supply.

Third, the availability, success, and quality of green power products will hinge on several factors, including the market rules and public policies adopted in a restructured marketplace. States with supportive public policies and market rules may help foster a credible and sizable green power market; states without supportive rules and policies may thwart the development of this new market. The basic rules that govern the operation and structure of the market itself will perhaps have the most impact on the ability of green power marketers to successfully compete. Most importantly, default service that is offered at or below the wholesale market price of power will hamper competition by discouraging customer switching and will be detrimental to green power by requiring higher-price premiums. At the same time, more overt forms of renewables policies will likely be required to fully support the renewable energy industries and augment the green power market at least in the near term.

Fourth, to enhance the credibility of the green power market, facilitate the comparison of different electricity products, educate and influence consumers, and improve overall product quality, environmental disclosure policies and certification programs may also play an important role in the growth of green power markets. In fact, to mitigate ongoing concerns about product quality and the truthfulness of green claims, a number of states have already passed disclosure laws, and the voluntary Green-e program is certifying green products in California and Pennsylvania.
Finally, it must be acknowledged that whether restructuring will launch a durable, credible, and sustainable market for green power is not yet known. Experience with the green power market to date has been mixed and there has been considerable debate on the merits and drawbacks of green marketing as a tool for commercializing renewable energy technologies. Moreover, it will clearly take some time before sufficient experience is gained to estimate future demand and the resultant impact on renewables supply with any precision. Retail competition will, however, clearly mean more to consumers than just the opportunity to purchase cheaper electricity. Based on the evidence provided in this paper, it is clear that there is at least a niche market of consumers, both residential and nonresidential, that are willing to pay a premium for green power products. Moreover, evidence from the pilot programs and full retail competition suggests that a good fraction of residential consumers that switch suppliers might be induced to select a green power product. Unfortunately, the evidence also shows that, unless electricity markets are explicitly designed to encourage switching, few residential consumers will be interested in switching providers in the near term. Accordingly, it is important for green power marketers, advocates, and others to have realistic expectations about the likely near-term consumer response to green options, and to place a particular emphasis on those market rules that will affect the ultimate size and credibility of the green market. 


\section{Appendix A. Green Power Products}

Table A-1. Green Power Products Offered under Retail Competition to Residential Consumers*

\begin{tabular}{|c|c|c|}
\hline Company and Product & Resource Mix & $\begin{array}{c}\text { Product Price for Average } \\
\text { Residential Consumer** }\end{array}$ \\
\hline \multicolumn{3}{|l|}{ New Hampshire: Pilot } \\
\hline $\begin{array}{l}\text { Green Mountain Energy } \\
\text { Partners }\end{array}$ & $97 \%$ hydro, $3 \%$ nuclear and fossil fuel & $2.66 \notin / \mathrm{kWh}$ (generation only) \\
\hline Northfield Mountain Energy & $\begin{array}{l}\text { Because pumped storage hydro is involved, it } \\
\text { is not possible to specify the exact shares of } \\
\text { fuel sources included }\end{array}$ & $3.11 \phi / \mathrm{kWh}$ (generation only) \\
\hline Working Assets Green Power & $\begin{array}{l}\text { No nuclear, coal, or Hydro-Quebec; in first } \\
\text { quarter } 1997 \text {, resource mix included } 51 \% \\
\text { hydro, } 3 \% \text { landfill gas, } 41 \% \text { gas, } 1 \% \text { oil, and } \\
4 \% \text { unspecified }\end{array}$ & $3.50 \notin / \mathrm{kWh}$ (generation only) \\
\hline \multicolumn{3}{|l|}{ Massachusetts: Pilot } \\
\hline AllEnergy & $\begin{array}{l}10 \% \text { hydro, } 6 \% \text { other renewables, } 38 \% \text { coal, } \\
22 \% \text { gas, } 10 \% \text { oil, } 14 \% \text { nuclear; three price } \\
\text { options impact SO2 emissions credits retired } \\
\text { and PV panels installed }\end{array}$ & $\begin{array}{l}\text { 3 Options: } \\
3.01 \phi / \mathrm{kWh} \text { (generation only) } \\
3.21 \phi / \mathrm{kWh} \text { (generation only) } \\
3.41 \phi / \mathrm{kWh} \text { (generation only) }\end{array}$ \\
\hline Enova Energy & $\begin{array}{l}5.7 \% \text { hydro, } 2.3 \% \text { other renewables, } 57.3 \% \\
\text { nuclear, } 20.9 \% \text { coal, } 13.9 \% \text { oil, } 0.1 \% \text { gas }\end{array}$ & $2.50 \notin / \mathrm{kWh}$ (generation only) \\
\hline Northfield Mountain Energy & $100 \%$ hydro & $2.60 \notin / \mathrm{kWh}$ (generation only) \\
\hline Working Assets Green Power & $\begin{array}{l}\text { No nuclear, coal, or Hydro-Quebec; } 30 \%-45 \% \\
\text { hydro, } 3 \%-10 \% \text { other renewables, } 35 \%-50 \% \\
\text { gas, } 0 \%-0.5 \% \text { oil }\end{array}$ & $3.35 ф / \mathrm{kWh}$ (generation only) \\
\hline \multicolumn{3}{|l|}{ Oregon: Pilot } \\
\hline $\begin{array}{l}\text { Electric Lite Inc. } \\
\text { Electric Lite Green }\end{array}$ & $\begin{array}{l}26 \% \text { geothermal, } 25 \% \text { landfill gas, } 25 \% \text { hydro, } \\
\text { and } 24 \% \text { natural gas, oil, coal, and nuclear }\end{array}$ & $\begin{array}{l}1 \notin / \mathrm{kWh} \text { premium above Electric Lite's } \\
\text { low-cost product; avg. bill increases } \\
\$ 7 / \text { month }\end{array}$ \\
\hline \multicolumn{3}{|l|}{ California: Full Competition*** } \\
\hline $\begin{array}{c}\text { cleen 'n green } \\
\text { green } 50\end{array}$ & $\begin{array}{l}50 \% \text { eligible renewables (undesignated mix of } \\
\text { solar, wind, small hydro, biomass, and } \\
\text { geothermal; includes } 10 \% \text { new renewables); } \\
50 \% \text { large hydro and natural gas }\end{array}$ & $\begin{array}{l}0.98 \notin / \mathrm{kWh} \text { premium over } 1999 \text { utility } \\
\text { rates; avg. bill increases } \$ 5.4 / \text { month }\end{array}$ \\
\hline $\begin{array}{l}\text { cleen 'n green } \\
\text { green } 100\end{array}$ & $\begin{array}{l}100 \% \text { eligible renewables (undesignated mix of } \\
\text { solar, wind, small hydro, biomass, and } \\
\text { geothermal; includes } 20 \% \text { new renewables) }\end{array}$ & $\begin{array}{l}1.98 \phi / \mathrm{kWh} \text { premium over } 1999 \text { utility } \\
\text { rates; avg. bill increases } \$ 10.9 / \text { month }\end{array}$ \\
\hline $\begin{array}{r}\text { Commonwealth } \\
\text { GreenSmart } \\
\end{array}$ & $\begin{array}{l}100 \% \text { eligible renewables (geothermal and } \\
\text { biomass) }\end{array}$ & $\begin{array}{l}0.12 \phi / \mathrm{kWh} \text { discount off } 1999 \text { utility } \\
\text { rates; avg. bill decreases } \$ 0.66 / \text { month }\end{array}$ \\
\hline $\begin{array}{l}\text { Edison Source } \\
\text { EarthSource } 2000\end{array}$ & $\begin{array}{l}100 \% \text { eligible renewables (undesignated mix of } \\
\text { solar, wind, small hydro, biomass, and } \\
\text { geothermal; includes } 10 \% \text { new renewables) }\end{array}$ & $\begin{array}{l}3.47 \phi / \mathrm{kWh} \text { premium over } 1999 \text { utility } \\
\text { rates; avg. bill increases } \$ 19.1 / \text { month }\end{array}$ \\
\hline $\begin{array}{l}\text { Edison Source } \\
\text { EarthSource } 100\end{array}$ & $\begin{array}{l}100 \% \text { eligible renewables (undesignated mix of } \\
\text { solar, wind, small hydro, biomass, and } \\
\text { geothermal) }\end{array}$ & $\begin{array}{l}3.07 \phi / \mathrm{kWh} \text { premium over } 1999 \text { utility } \\
\text { rates; avg. bill increases } \$ 16.9 / \text { month }\end{array}$ \\
\hline Edison Source & $50 \%$ eligible renewables (undesignated mix of & $1.36 \notin / \mathrm{kWh}$ premium over 1999 utility \\
\hline
\end{tabular}




\begin{tabular}{|c|c|c|}
\hline $\begin{array}{l}\text { Company and Product } \\
\text { EarthSource } 50\end{array}$ & $\begin{array}{l}\text { Resource Mix } \\
\text { solar, wind, small hydro, biomass, and } \\
\text { geothermal), } 50 \% \text { California System Power }\end{array}$ & $\begin{array}{c}\text { Product Price for Average } \\
\text { Residential Consumer** } \\
\text { rates; avg. bill increases } \$ 7.5 / \text { month }\end{array}$ \\
\hline $\begin{array}{l}\text { Enron Energy Services } \\
\text { Earth Smart Power } \\
\text { (Product Discontinued) }\end{array}$ & $\begin{array}{l}50 \% \text { eligible renewables (includes geothermal, } \\
\text { biomass, and new wind), } 50 \% \text { large hydro and } \\
\text { natural gas }\end{array}$ & $\begin{array}{l}1.0 \notin / \mathrm{kWh} \text { premium over } 1999 \text { utility } \\
\text { rates; avg. bill increases } \$ 5.5 / \text { month }\end{array}$ \\
\hline $\begin{array}{l}\text { Green Mountain Energy } \\
\text { Resources } \\
\text { Wind for the Future }\end{array}$ & $\begin{array}{l}75 \% \text { eligible renewables (small hydro, biomass, } \\
\text { and geothermal; includes } 10 \% \text { new wind over } \\
\text { time), } 25 \% \text { large hydro }\end{array}$ & $\begin{array}{l}2.1 \phi / \mathrm{kWh} \text { premium over } 1999 \text { utility } \\
\text { rates; avg. bill increases } \$ 11.6 / \text { month }\end{array}$ \\
\hline $\begin{array}{l}\text { Green Mountain Energy } \\
\text { Resources } \\
75 \% \text { renewable } \\
\text { product } \\
\end{array}$ & $\begin{array}{l}75 \% \text { eligible renewables (small hydro, biomass, } \\
\text { and geothermal), } 25 \% \text { large hydro }\end{array}$ & $\begin{array}{l}1.2 \phi / \mathrm{kWh} \text { premium over } 1999 \text { utility } \\
\text { rates; avg. bill increases } \$ 6.6 / \text { month }\end{array}$ \\
\hline $\begin{array}{l}\text { Green Mountain Energy } \\
\text { Resources } \\
\text { Water Power }\end{array}$ & $100 \%$ hydro & $\begin{array}{l}0.975 \phi / \mathrm{kWh} \text { premium over } 1999 \\
\text { utility rates; avg. bill increases } \\
\$ 5.4 / \text { month }\end{array}$ \\
\hline $\begin{array}{l}\text { Keystone Energy Services } \\
\text { EarthChoice } 100\end{array}$ & $\begin{array}{l}100 \% \text { eligible renewables (undesignated mix of } \\
\text { solar, wind, small hydro, biomass, and } \\
\text { geothermal) }\end{array}$ & $\begin{array}{l}2.46 \notin / \mathrm{kWh} \text { premium over } 1999 \text { utility } \\
\text { rates; avg. bill increases } \$ 13.5 / \text { month }\end{array}$ \\
\hline $\begin{array}{l}\text { PG\&E Energy Services } \\
\text { Clean Choice } 100\end{array}$ & $\begin{array}{l}100 \% \text { eligible renewables (undesignated mix of } \\
\text { solar, wind, small hydro, biomass, and } \\
\text { geothermal; includes } 25 \% \text { new renewables over } \\
\text { time) }\end{array}$ & $\begin{array}{l}2.29 \notin / \mathrm{kWh} \text { premium over } 1998 \text { utility } \\
\text { rates; avg. bill increases } \$ 12.6 / \text { month }\end{array}$ \\
\hline $\begin{array}{l}\text { PG\&E Energy Services } \\
\text { Clean Choice } 50\end{array}$ & $\begin{array}{l}50 \% \text { eligible renewables (undesignated mix of } \\
\text { solar, wind, small hydro, biomass, and } \\
\text { geothermal; includes } 13 \% \text { new renewables over } \\
\text { time), } 50 \% \text { large hydro }\end{array}$ & $\begin{array}{l}1.63 \phi / \mathrm{kWh} \text { premium over } 1998 \text { utility } \\
\text { rates; avg. bill increases } \$ 8.9 / \text { month }\end{array}$ \\
\hline $\begin{array}{l}\text { PG\&E Energy Services } \\
\text { Clean Choice } 20\end{array}$ & $\begin{array}{l}20 \% \text { eligible renewables (undesignated mix of } \\
\text { solar, wind, small hydro, biomass, and } \\
\text { geothermal; includes } 5 \% \text { new renewables over } \\
\text { time), } 80 \% \text { large hydro }\end{array}$ & $\begin{array}{l}0.71 \varnothing / \mathrm{kWh} \text { premium over } 1998 \text { utility } \\
\text { rates; avg. bill increases } \$ 3.9 / \text { month }\end{array}$ \\
\hline \multicolumn{3}{|l|}{$\begin{array}{l}\text { Massachusetts and Rhode } \\
\text { Island: Full Competition }\end{array}$} \\
\hline $\begin{array}{l}\text { AllEnergy } \\
\text { ReGen }\end{array}$ & $\begin{array}{l}\text { Each } 2,000 \mathrm{kWh} / \mathrm{yr} \text { block: first year-99.5\% } \\
\text { new landfill gas, } 0.5 \% \text { new PV; second year- } \\
84 \% \text { new landfill gas, } 1 \% \text { new PV, } 15 \% \text { new } \\
\text { wind }\end{array}$ & $\begin{array}{l}\$ 8.0 / \text { month for first block; } \$ 6.0 / \text { month } \\
\text { for other blocks }\end{array}$ \\
\hline \multicolumn{3}{|l|}{ Pennsylvania: Full Competition } \\
\hline $\begin{array}{l}\text { Green Mountain Energy } \\
\text { Resources } \\
\quad \text { Eco Smart }\end{array}$ & $\begin{array}{l}99 \% \text { natural gas and/or large hydro, } 1 \% \text { new } \\
\text { landfill gas }\end{array}$ & $\begin{array}{l}\text { Depends on service territory, e.g.: } \\
\text { PECO— } 0.4 \notin / \mathrm{kWh} \text { reduction on } 1999 \\
\text { utility rates; avg. bill decreases } \\
\$ 3 / \text { month } \\
\text { PP\&L-0.7 } \& / \mathrm{kWh} \text { premium over } 1999 \\
\text { utility rates; avg. bill increases } \\
\$ 5 / \text { month }\end{array}$ \\
\hline
\end{tabular}




\begin{tabular}{|c|c|c|}
\hline Company and Product & Resource Mix & $\begin{array}{l}\text { Product Price for Average } \\
\text { Residential Consumer** }\end{array}$ \\
\hline $\begin{array}{l}\text { Green Mountain Energy } \\
\text { Resources } \\
\quad \text { Enviro Blend }\end{array}$ & $\begin{array}{l}47 \% \text { existing small hydro and landfill gas, } 3 \% \\
\text { new landfill gas, } 50 \% \text { natural gas and/or large } \\
\text { hydro }\end{array}$ & $\begin{array}{l}\text { Depends on service territory, e.g.: } \\
\text { PECO_0.5 } / \mathrm{kWh} \text { premium over } \\
1999 \text { utility rates; avg. bill increases } \\
\$ 4 / \text { month } \\
\text { PP\&L-1.3 } / \mathrm{kWh} \text { premium over } 1999 \\
\text { utility rates; avg. bill increases } \\
\$ 9 / \text { month }\end{array}$ \\
\hline $\begin{array}{l}\text { Green Mountain Energy } \\
\text { Resources } \\
\quad \text { Nature's Choice }\end{array}$ & $\begin{array}{l}95 \% \text { existing small hydro and landfill gas, } 5 \% \\
\text { new landfill gas }\end{array}$ & $\begin{array}{l}\text { Depends on service territory, e.g.: } \\
\text { PECO-1.1 } \notin / \mathrm{kWh} \text { premium over } \\
1999 \text { utility rates; avg. bill increases } \\
\text { \$9/month } \\
\text { PP\&L-2.3 } \& / \mathrm{kWh} \text { premium over } 1999 \\
\text { utility rates; avg. bill increases } \\
\text { \$17/month }\end{array}$ \\
\hline $\begin{array}{l}\text { Conectiv } \\
\text { Nature's Power } 100\end{array}$ & $\begin{array}{l}100 \% \text { eligible renewable energy, including } \\
50 \% \text { biomass and } 50 \% \text { small hydro }\end{array}$ & $\begin{array}{l}\text { In PECO's service territory, } 0.5 \notin / \mathrm{kWh} \\
\text { premium over } 1999 \text { utility rates; avg. } \\
\text { bill increases } \$ 4 / \text { month }\end{array}$ \\
\hline $\begin{array}{l}\text { Conectiv } \\
\text { Nature's Power } 50\end{array}$ & $\begin{array}{l}50 \% \text { eligible renewable energy ( } 25 \% \text { biomass, } \\
25 \% \text { small hydro) and } 50 \% \text { nonrenewable } \\
\text { resources }\end{array}$ & $\begin{array}{l}\text { In PECO's service territory, } 0.2 \phi / \mathrm{kWh} \\
\text { reduction on } 1999 \text { utility rates; avg. } \\
\text { bill decreases } \$ 1.2 / \text { month }\end{array}$ \\
\hline
\end{tabular}

* $\quad$ Note that most of the products included in this table are only those that are differentiated based on their power content. Products that use other forms of environmental claims are not included (except for the Massachusetts pilot, which includes all of the "green" options selected by the pilot administrator).

** Price estimates are not all presented on equal terms and are therefore not all directly comparable. California prices reflect an average usage of $550 \mathrm{kWh} /$ month. Pennsylvania prices reflect an average usage of $750 \mathrm{kWh} / \mathrm{month}$.

*** For the California and Pennsylvania products, "eligible renewables" are defined to include solar, wind, geothermal, biomass, and hydro less than or equal to $30 \mathrm{MW}$.

Sources include: Holt and Fang (1997), Rothstein and Fang (1997), Wiser and Pickle (1998), and a variety of news releases, direct mail, and web sites. 


\section{End Notes}

1. Energy Information Administration. The Changing Structure of the Electric Power Industry: Selected Issues, 1998. DOE/EIA-0620. July 1998.

2. Energy Center of Wisconsin. Green Power in Perspective: Lessons from the Marketing of Consumer Goods. Madison, Wisconsin. December 1997.

Nakarado, G. "A Marketing Orientation is the Key to a Sustainable Energy Future.” Energy Policy, 24 (2), 1996.

Rader, N. and Short, W. "Competitive Retail Markets: Tenuous Ground for Renewable Energy." The Electricity Journal, 11 (3), 1998.

Wiser, R. and Pickle, S. Green Marketing, Renewables, and Free Riders: Increasing Customer Demand for a Public Good. Lawrence Berkeley National Laboratory, LBNL-40636. Berkeley, California. 1997.

3. Energy Information Administration. The Changing Structure of the Electric Power Industry: Selected Issues, 1998. DOE/EIA-0620. July 1998.

4. For detailed descriptions of the first six pilots, see: Edison Electric Institute. Retail Pilot Programs: The First Six. Washington, D.C. 1997.

5. Landon, J. and Kahn, E. "Retail Access Pilot Programs: Where's the Beef?" The Electricity Journal, December 1996.

Lineweber, D. "What Competition Pilots Don't Tell You About Customer Choice in Competitive Markets.” Proceedings: $8^{\text {th }}$ National Energy Services Conference. June 1997.

6. For more detail, see: Holt, E. and Fang, J. The New Hampshire Retail Competition Pilot Program and the Role of Green Marketing. NREL Topical Issues Brief, National Renewable Energy Laboratory. November 1997.

7. University of New Hampshire Survey Center. Retail Electric Competition Pilot Program Survey Report. Conducted for the NHPUC. January 1997.

8. For more detail, see: Rothstein, S. and Fang, J. Green Marketing in the Massachusetts Electric Company Retail Competition Pilot Program. NREL Topical Issues Brief, National Renewable Energy Laboratory. October 1997.

Titus, E. and Fox, E. “An Evaluation of the Massachusetts Electric Company's Retail Choice Pilot: An Overview.” Proceedings: 1997 Energy Evaluation Conference. Chicago, Illinois. 1997.

9. Abe, Jon. Personal communication. Environmental Futures, Inc. January 28, 1998.

10. This section is based in large part on two market assessments of the pilot program: Assessment of the 
PGE Introductory Customer Choice Program: Interim Report \#1. Submitted to The PGE Introductory Customer Choice Program Task Force. June 8, 1998.

Assessment of the PGE Introductory Customer Choice Program: Interim Report \#2. Submitted to The PGE Introductory Customer Choice Program Task Force. August 19, 1998.

Also see: "Energy Companies End Price Competition Test.” The Oregonian. July 10, 1998.

11. Phillips-Israel, Kathy. Personal Communication. PGE. September 16, 1998.

12. For more information on the California experience with green power marketing, see: Wiser, R. and Pickle, S. Selling Green Power in California: Product, Industry and Market Trends. Lawrence Berkeley National Laboratory, LBNL-41807. Berkeley, California. May 1998.

Wiser, R., Golove, W. and Pickle, S. "California's Electric Market: What's in it for the Customer." Public Utilities Fortnightly, August 1998.

13. Tennis, Michael. Personal Communication. AllEnergy. September 14, 1998.

14. This section is based on: Wiser, R., Pickle, S. and Eto, J. "Details, Details... The Impact of Market Rules on Emerging "Green” Energy Markets." Proceedings: ACEEE 1998 Summer Study on Energy Efficiency in Buildings. Pacific Grove, California. August 1998.

15. Wiser, R., Pickle, S. and Eto, J. "Details, Details... The Impact of Market Rules on Emerging “Green” Energy Markets.” Proceedings: ACEEE 1998 Summer Study on Energy Efficiency in Buildings. Pacific Grove, California. August 1998.

16. Winneg, K., Herrmann, M., Levy, A. and Roe, B. Summary Report, Baseline Survey. Consumer Knowledge, Practices, and Attitudes: Electric Utility Deregulation and Customer Choice. National Council on Competition and the Electric Industry. 1998

Levy, A., Teisl, M., Halverson, L. and E. Holt. Information Disclosure for Electricity Sales: Consumer Preferences from Focus Groups. National Council on Competition and the Electric Industry. 1997.

Teisl, M., Halverson, L. and E. Holt. Information Disclosure for Electricity Sales: Consumer Preferences from Focus Groups-West Coast. National Council on Competition and the Electric Industry. 1997.

University of New Hampshire Survey Center. Retail Electric Competition Pilot Program Survey Report. Conducted for the NHPUC. January 1997.

17. Center for Clean Air Policy. Policy Handbook: Disclosure in the Electricity Marketplace. Draft. March 1998.

18. Harris, J. and Casey-McCabe, N. "Energy-Efficient Product Labeling: Market Impacts on Buyers and Sellers." Proceedings of the ACEEE Summer Study on Energy Efficiency. Pacific Grove, California. August 1996. 
ABT Associates. Determinants of Effectiveness for Environmental Certification and Labeling Programs. Environmental Protection Agency, EPA 742-R-94-001. Washington, D.C. 1994.

Dyer, R. and Maronick, T. "An Evaluation of Consumer Attitudes and Use of Energy Labels in the Purchase of Major Appliances: A Longitudinal Analysis." Journal of Public Policy and Management, 7, 1988.

Taylor, D. “Certification Marks_-Success or Failure?” The Journal of Marketing, 23 (1), 1958.

Parkinson, T. "The Role of Seals and Certifications of Approval in Consumer Decision-Making." The Journal of Consumer Affairs, 9 (1), 1975.

Grodsky, J. "Certified Green: The Law and Future of Environmental Labeling." The Yale Journal on Regulation, 10, 1993.

Menell, P. "Structuring a Market-Oriented Federal Eco-Information Policy." Maryland Law Review, 54 (4), 1995.

Laric, M. and Sarel, D. "Consumer (Mis)perceptions and Usage of Third Party Certification Marks, 1972 and 1980: Did Public Policy Have an Impact?” Journal of Marketing 45, 1981.

19. ABT Associates. Status Report on the Use of Environmental Labels Worldwide. Environmental Protection Agency, EPA 742-R-9-93-001. Washington, D.C. 1993.

20. Rabago, K., Wiser, R. and Hamrin, J. “The Green-e Program: An Opportunity for Customers.” The Electricity Journal, 11 (1), 1998.

21. Rader, N. "Green Buyers Beware: A Critical Review of 'Green Electricity' Products.” Public Citizen. October 1998.

22. For more information on renewable energy financing and green power marketing issues, see: Wiser, R. and Pickle, S. Financing Investments in Renewable Energy: The Role of Policy Design and Restructuring. Lawrence Berkeley National Laboratory, LBNL-39826. Berkeley, California. March 1997.

Hamrin, J., Wiser, R., McCormack, K. and Holt, E. New Markets for Wind: The Supplier Response. Prepared for the National Wind Coordinating Committee. Draft. August 1998.

23. Farhar, B. and Houston, A. "Willingness to Pay for Electricity from Renewable Energy." Proceedings: 1996 ACEEE Summer Study on Energy Efficiency in Buildings. Pacific Grove, California. August 1996.

24. Holt, E., and Wiser, R. Understanding Consumer Demand for Green Power. Prepared for the National Wind Coordinating Committee. Draft. August 1998.

Wiser, R. and Pickle, S. Selling Green Power in California: Product, Industry and Market Trends. Lawrence Berkeley National Laboratory, LBNL-41807. Berkeley, California. May 1998. 
Kasius, A. and Seth, C. "Environmental Performance Through Energy Procurement in Competitive Markets.” Corporate Environmental Strategy 5 (2), 1998.

Holt, E. Green Power for Business: Good News from Traverse City. Renewable Energy Policy Project, Research Report \#1. July 1997.

25. Rogers, E. Diffusion of Innovations. The Free Press. New York, NY, 1962.

26. Electric Power Research Institute. New Product Introductions: Case Histories from Other Industries. Prepared by Putnam, Hayes \& Bartlett, Inc. TP-106901. 1996.

27. Wiser, R. and Pickle, S. Selling Green Power in California: Product, Industry and Market Trends. Lawrence Berkeley National Laboratory, LBNL-41807. Berkeley, California. May 1998. 


\section{Topical Issues Briefs Previously Published by the National Renewable Energy Laboratory*}

The New Hampshire Retail Competition Pilot Program and the Role of Green Marketing

November 1997

NREL/TP-260-23446

Green Marketing in the Massachusetts Electric Company Retail Competition Pilot Program

October 1997

NREL/TP-460-23507

Power Marketing and Renewable Energy

September 1997

NREL/SP-460-21651

Net Metering Programs

September 1996

NREL/SP-460-21427

Small Turbines in Distributed Utility Application:

Natural Gas Pressure Supply Requirements

May 1996

NREL/SP-461-21073

*See inside cover for instructions to order Topical Issues Briefs 
Public reporting burden for this collection of information is estimated to average 1 hour per response, including the time for reviewing instructions, searching existing data sources, gathering and maintaining the data needed, and completing and reviewing the collection of information. Send comments regarding this burden estimate or any other aspect of this Davis Highway, Suite 1204, Arlington, VA 22202-4302, and to the Office of Management and Budget, Paperwork Reduction Project (0704-0188), Washington, DC 20503.

\begin{tabular}{|l|l|l|l|l}
\hline 1. AGENCY USE ONLY (Leave blank) & $\begin{array}{l}\text { 2. REPORT DATE } \\
\text { March 1999 }\end{array}$ & $\begin{array}{l}\text { 3. REPORT TYPE AND DATES COVERED } \\
\text { Topical Issues Brief }\end{array}$ \\
\hline
\end{tabular}

4. TITLE AND SUBTITLE Green Power Marketing in Retail Competition: An Early Assessment

6. AUTHOR(S)

Kevin Porter, Ryan Wiser (LBNL)

7. PERFORMING ORGANIZATION NAME(S) AND ADDRESS(ES)

National Renewable Energy Laboratory

1617 Cole Boulevard

Golden, Colorado 80401-3393

8. PERFORMING ORGANIZATION REPORT NUMBER

TP-620-25939
9. SPONSORING/MONITORING AGENCY NAME(S) AND ADDRESS(ES)

U.S. Department of Energy

1000 Independence Ave., SW

Washington, DC 20585

11. SUPPLEMENTARY NOTES

Part of the Topical Issues Brief series of publications.

12a. DISTRIBUTION/AVAILABILITY STATEMENT

National Technical Information Service

U.S. Department of Commerce

5285 Port Royal Road

Springfield, VA 22161
10. SPONSORING/MONITORING AGENCY REPORT NUMBER

13. ABSTRACT (Maximum 200 words)

Green power marketing - the business of selling electricity products or services based in part on their environmental values - is still in an early stage of development. This Topical Issues Brief presents a summary of early results with green power marketing under retail competition, covering both fully competitive markets and relevant direct access pilot programs. The brief provides an overview of green products that are or were offered, and discusses consumers' interest in these products. Critical issues that will impact the availability and success of green power products under retail competition are highlighted.

14. SUBJECT TERMS

Electric utility restructuring; deregulation; green power; retail competition

15. NUMBER OF PAGES

28

16. PRICE CODE

17. SECURITY CLASSIFICATION OF REPORT unclassified
18. SECURITY CLASSIFICATION OF THIS PAGE Unclassified
19. SECURITY CLASSIFICATION OF ABSTRACT Unclassified
20. LIMITATION OF ABSTRACT UL

NSN 7540-01-280-5500

Standard Form 298 (Rev. 2-89) Prescribed by ANSI Std. Z39-18 